\title{
The Social Construction of Disease: Two Metaphors of the Tuberculous Patient
}

\author{
Caralee E. Caplan*, B.A.
}

* To whom correspondence should be addressed: Faculty of Medicine, McGill University, Montreal, QC, Canada H3G 1 Y6

Although virtually every human condition, for better or worse, carries its share of myths and associations, few diseases can boast a metaphorical history as rich and varied as that of tuberculosis. One of the oldest diseases, tuberculosis is known to have affected Western Europeans in the Neolithic era and Egyptians in ancient times. Inevitably, epidemiological shifts, advances in our understanding of the biological basis of disease, and the vicissitudes of medical practice give rise to concomitant changes in the social construction of illness and the ill. Donning new names to adjust to these changes, tuberculosis has also been called "phthisis" (from the Greek "phthoe," meaning "individual shriveling up under intense heat"), "consumption" (from the Latin "consumere," meaning "to eat up or devour"), and "scrofula" (a designation for tuberculosis affecting the cervical lymph nodes) (1). The modern term "tuberculosis," coined in the mid-19th-century to describe the characteristic "tubercles" in affected organs, became the preferred name for the disease only in the early20th century (2). In her essay titled "Illness as Metaphor," Susan Sontag explains, "it is hardly possible to take up one's residence in the kingdom of the ill unprejudiced by the lurid metaphors with which it has been landscaped" (3). Thus, the late-19th-century "consumptive type" and the late-20th-century tuberculous patient, although contending with precisely the same physical ailment, have been forced to grapple with entirely different social conceptions and misconceptions of their disease.

In the late-18th and early-19th centuries, little could be done for people suffering from tuberculosis, since the etiology of the disease was poorly understood and physicians often diagnosed the disease once it had already become fairly well advanced. In the absence of any other predictors of disease, medical practitioners could do little more than generalize from their observations of individual patients. They described the classic candidate for consumption largely in terms of physical appearance and temperament:

a clean fair skin, bright eyes, white teeth, delicate rosy complexion, sanguine temperament, great sensibility, thick lips, and large veins. Persons who are very small around the breast, that is, those of a narrow chest, and prominent shoulders, are also more liable to this disease than others (4).

Although some practitioners described a second phthisical type - the virtual opposite of the first, with rough skin and a dull intellect - a remarkable majority subscribed to the first description. As McMurry explains, the description of the phthisical type endured largely because

it was at least somewhat accurate in predicting victims. This accuracy resulted from the inclusion of people already suffering from consumption in the category of potential victims. . Progressive but gradual emaciation would account for thin bodies and cause necks to appear long and 
shoulders protruding. Damage to the lungs could decrease chest size, protracted ill health could make the skin pale, and undetected fever could render eyes bright long before more distinct symptoms appeared. When the classic symptoms followed, as they often did, they served as powerful confirmation that the previously observed characteristics had indeed presaged consumption (5).

Thus, medical practitioners believed that "constitution," probably inherited from one's parents, determined one's susceptibility to consumption.

Although the notion of constitution as a predictor of disease susceptibility relied largely on an evaluation of externals, it also touched to the very core of the individual personality. Beyond their distinctive physical characteristics, phthisical types were believed to be "young talented individuals," who

display enormous intellectual capacity of the creative kind. . They are in a constant state of nervous irritability, but despite the fact that it hurts their physical condition, they keep on working and produce their best works (6).

In the consumptive patient, mind and body were imagined as existing at odds with one another: even as the body becomes "consumed" and "wasted" by disease, the mind continues to expand and create. So firmly ingrained was the idea of the superior intelligence and creativity of the consumptive that after the discovery of the tubercle bacillus by Koch in 1882, certain members of the medical community postulated the existence of a tuberculous "toxin" that produced cerebral effects of heightened alertness or inspired intoxication (7).

Indeed, artistic creation and the consumptive condition became so intimately linked in the 19th-century consciousness that "robust health" no longer seemed consistent with an artistic temperament. Elizabeth Barrett Browning, herself afflicted with consumption, overheard the revealing question of a contemporary, "Is it possible that genius is only scrofula?" (8) In a sense, consumption gained a reputation for being the price artists paid for their enormous talent. Furthermore, the tendency of artists to fall prey to consumption was seen not only as a matter of constitution but also of lifestyle: the hours of grueling work in closed spaces, the flights of passion, and even the harsh words of critics were believed to weaken artists and render them more susceptible to the consumptive disease. Shelley's "Adonais: An Elegy on the Death of John Keats" celebrates Keats as a great poet who had been killed by "the shock of savage reviews" (9). Keats, of course, had contracted tuberculosis while nursing his consumptive brother Tom, and died of his disease at the age of 26.

The example of Keats's experience of tuberculosis highlights yet another stereotype of the consumptive individual: those afflicted with consumption were believed to be not only the best and the brightest that humanity had to offer but also the most sensitive and passionate. In a letter to his fiancée Fanny Brawne a year before his death, Keats links his physical disease to a surplus of passion:

'Tis certain I shall never recover if I am to be long separate from you. . . I am literally worn to death, which seems my only recourse. . You are to me an object intensely desirable - the air I breathe in a room empty of you is unhealthy. (10)

As Sontag explains, the bright eyes and "hectic glow" of feverish consumptives tended to confirm 19thcentury views of tuberculosis as a "disease of passion" (11). In some ways, consumptives were seen as too good, too spiritual to survive in the material world. In Harriet Beecher Stowe's Uncle Tom's Cabin, little Evangeline, soon to die of consumption, is as pure and angelic as her name would imply:

The child rose, and pointed her little hand to the sky; the glow of evening lit her golden hair and flushed cheek with a kind of unearthly radiance, and her eyes were bent earnestly on the skies. . . Has there ever been a child like Eva? Yes, there have been; but their names are always on 
gravestones, and their sweet smiles, their heavenly eyes, their singular words and ways, are among the buried treasures of yearning hearts (12).

Death by consumption thus becomes aestheticized and spiritualized, as the heavenly and perfect soul leaves the confines of the earthly and imperfect body.

Certainly, the works and journals of artists provide some of the most revealing accounts of social conceptions of tuberculosis and their effects on the individual's attempt to heal. In her journal, writer Katherine Mansfield unveils her struggle to make suffering bearable through acts of the mind: "One must submit. Do not resist. Take it. Be overwhelmed. Accept it fully. Make it part of life" (13). Keats, Shelley, and many other Romantics fled to warmer climes, to Italy and to the south of France, to escape the cold, damp English weather, which was believed to exacerbate consumption. The list of 19th- and early-20th-century novels whose casts include consumptive characters is almost as long as the list of well-known consumptive artists: Thomas Mann's The Magic Mountain, Charles Dickens's Dombey and Son, Emily Brontë's Wuthering Heights all contribute to the notion of consumptives as at once sensual and sensitive, passionate and angelic, sickly and brilliant.

With the explosion of knowledge that followed Koch's paper titled The Etiology of Tuberculosis in 1882 (14), the advent of roentgenography in 1895, the development of vaccines, and the inauguration of the era of antibiotics, medicine took great strides in the diagnosis, treatment, and prevention of tuberculosis. In The People versus Tuberculosis, Hunt describes the "sixty-year history of the long struggle to eliminate TB" (15). Up until the 1980's, the prevalence of tuberculosis worldwide was on the decline (16). But as Dr. Frank Ryan argues in his recent book The Forgotten Plague: How the Battle Against Tuberculosis Was Won - and Lost, the war against tuberculosis is far from over (17). Just when tuberculosis seemed likely to be resigned to the annals of history, the 1980's witnessed a resurgence so impressive that health care officials warned the community of an advancing tuberculosis epidemic.

The tuberculosis epidemic is intimately linked to another epidemic at the center of late-20th-century consciousness.

... this new plague would soon become familiar worldwide under its frightening acronym, AIDS. How curious it seemed that in 1978, the year when the first few cases of this previously unknown contagion were reported, that the infection rate for tuberculosis began to rise again in New York (18).

Since then, numerous authors have argued that "HIV infection is increasing the incidence of TB" (19). Indeed, a recent study concluded that HIV-induced immunosuppression is an important contributor to the tuberculosis epidemic, accounting for a minimum of 30\% of excess tuberculosis cases from 1985 to 1990 (20). The Annual Review of Medicine for 1995 similarly reported a correlation between the increases in the reported number of tuberculosis cases and the trend of HIV infection, "with respect to geography and demographic groups" (21).

According to the Annual Review, the incidence of tuberculosis in persons with AIDS is almost 500 times that in the general population (22). Tuberculosis and HIV co-infection complicates not only the metaphors of disease but also the diagnosis of tuberculosis, since HIV-infected individuals are more frequently affected by extrapulmonary disease than non-immunosuppressed individuals. Furthermore, a patient afflicted by both tuberculosis and HIV must contend with the entire gamut of social conceptions of AIDS. As Sontag explains,

With AIDS, the shame is linked to an imputation of guilt; and the scandal is not at all obscure. Few wonder, Why me? Most people outside of sub-Saharan Africa who have AIDS know (or think they know) how they got it. It is not a mysterious affliction that seems to strike at random 
Transmitted through blood and other bodily fluids, HIV carries with it the connotation of contamination; when infection by the tubercle bacillus is superimposed upon HIV infection, the result is the sense of a fullfledged attack on a system particularly susceptible to microbial invasion and an individual particularly vulnerable to social stigma.

Beyond the specter of AIDS, however, is an entire range of social conditions that predispose to tuberculosis. Of the late-20th-century tuberculosis epidemic, Comstock writes,

Infection with HIV, resulting in the loss of cellular immunity, is widely blamed, but the roles of migration, poverty, malnutrition, and decreased tuberculosis control efforts cannot be excluded (24).

In large urban centers, tuberculosis is also associated with homelessness or unstable housing, alcohol abuse, and intravenous drug or cocaine use, all of which correlate with noncompliance with medication (25). Furthermore, studies show that $25 \%$ of new cases of tuberculosis in the United States in the past five years came from refugees and new immigrants from countries still experiencing high rates of tuberculosis infection (26). Poverty is among the most important risk factors for disease (27); thus, those living in crowded spaces with poor nutrition and without medical care - in other words, society's have-nots - have become the "tuberculous types" of the late-20th century. Far from the elevating, spiritualizing consumption that set the soul soaring beyond the physical world, today's tuberculosis seems to reaffirm the inescapability of one's material conditions: tuberculosis piles impoverishment on the already impoverished, stigma on the already stigmatized.

Of course, the emergence of such a new tuberculous type points to the responsibility that politicians and health care workers alike have failed to exert in the area of tuberculosis prevention. Recent studies agree that the shift of focus of the anti-tuberculosis campaign from the sanitoria and the hospital to out-patient care has contributed to the reemergence of tuberculosis as a central health-care concern (28). In the absence of adequate monitoring, patients fail to take their medication, allowing the bacilli to multiply and spread. Furthermore, in their "zeal for community-based drug therapy" (29), medicine and public policy have conspired to create strains of multiple-drug resistant tuberculosis, perhaps the greatest therapeutic challenge ever to emerge in the area of tuberculosis treatment and prevention.

Clearly, a very different metaphorical apparatus and set of values come into play to create the image of the 20th-century tuberculous type as opposed to the 19th-century consumptive. Although any individual can contract tuberculosis in any historical period, available treatments and living conditions affect the distribution of disease within society and, in turn, society's understanding of disease. In the pre-antibiotic era, when consumption was widespread throughout society, it was the great minds of the time who managed to capture the imaginations of their contemporaries and surround a poorly understood disease with all the glamor and romance of art. Today, when the social distribution of tuberculosis has become less democratic as a result of antibiotic therapy and improved standards of living for some, but not all, of society's members, tuberculosis has become imbued with the metaphors of poverty and marginalization.

The danger of metaphor, of course, lies in its totalizing capacity. By creating the illusion that only certain "types" are afflicted with certain diseases, by transforming individuals into geniuses or pariahs, metaphors create unrealistic expectations, distort self-conceptions, generate prejudices, and cast blame. Thus they interfere not only with the patient's capacity to create his/her own meaning but also with the physician's ability to diagnose disease in individuals who do not conform to the "type." Whether labeled an artistic and spiritual genius or one of society's unprotected outcasts, whether famous or forgotten, whether inspiring society's highest hopes or deepest fears, the tuberculous patient is, more than a type, a suffering human. 
Recent attempts to correct the mistakes of the past through "directly observed therapy" and "efforts to reduce the spread of tuberculosis in institutional settings, such as hospitals, shelters, and jails" have already had a significant impact on the rates of completion of treatment and the incidence of tuberculosis in New York City (30). It is undoubtedly in society's and the patient's best interests to continue these efforts, and, as Sontag suggests, to resist the temptation to turn illness into metaphor and people into types. For, in the end, the

changing face of tuberculosis over the last century is less a change in the disease itself than in the society that contracts, interprets, and endures it.

\section{ACKNOWLEDGEMENTS}

Special thanks to Jason P. Shaw for his help in conceiving the subject of this essay.

\section{REFERENCES}

1. Dubos R and Dubos J. The White Plague: Tuberculosis, Man and Society. Boston, MA: Little, Brown and Co.,pp. 71-72; 1952.

2. McMurry NM. "And I? I Am in a Consumption": The Tuberculous Patient, 1780-1930. Ann Arbor, MI: University Microfilms International, p. 6; 1985.

3. Sontag S, ed. Illness as Metaphor and AIDS and Its Metaphors. New York, NY: Doubleday, p. 4 ; 1990.

4. Whitney DH. The Family Physician and Guide to Health. (H. Gilbert, 1883), p. 60 qtd. in McMurry, p. 18.

5. McMurry, pp. 20-21.

6. Dubos, p. 60 .

7. Dubos, p. 59.

8. Dubos, p. 59.

9. Perkins D. English Romantic Writers. San Diego, CA: Harcourt Brace Jovanovich, p. 1046.

10. Forman MB, ed. The Letters of John Keats, v. 2. London: Oxford UP, pp. 540-541; 1931.

11. Sontag, p. 20.

12. Stowe HB, Uncle Tom's Cabin. New York, NY: Signet Classic, pp. 282-283; 1981.

13. Murry JM, ed. Journal of Katherine Mansfield. New York, NY: Alfred A. Knopf, p. 167; 1927.

14. Koch R. "The Etiology of Tuberculosis," trans. Dr. and Mrs. Max Pinner. New York, NY: National Tuberculosis Association; 1932.

15. Hunt LW. The People versus Tuberculosis. Danville, IL: Interstate Publishers, p. iii; 1966.

16. Comstock GW. Variability of tuberculosis trends in a time of resurgence. Clinical Infectious Diseases 19: 1015-1022; 1994.

17. Ryan F. The Forgotten Plague: How the Battle Against Tuberculosis Was Won--and Lost. Boston, MA: Little, Brown and Company; 1992. 
18. Ryan, p. 386.

19. FitzGerald JM, Grzybowski S, Allen EA. The impact of human immunodeficiency virus infection on tuberculosis and its control. Chest 100: 191-200; 1991.

20. Burwen DR, Bloch AB, Griffin LD, Ciesielski CA, Stern HA, Onorato IM. National trends in the concurrence of tuberculosis and acquired immunodeficiency syndrome. Archives of Internal Medicine 155: 1281-1286; 1995.

21. Huebner RE, Castro KG. The changing face of tuberculosis. Annual Review of Medicine 46: 47-55; 1995.

22. Huebner, p. 49.

23. Sontag, p. 112.

24. Comstock, p. 1015.

25. Brudney K, Dobkin J. Resurgent tuberculosis in New York City: human immunodeficiency virus, homelessness, and the decline of tuberculosis control programs. American Review of Respiratory Disease 144: 745-749; 1991.

26. Sbarbaro JA, Tuberculosis in the 1990s: epidemiology and therapeutic challenge. Chest 108: 58S-62S; 1995.

27. Simpson SQ, Jones PW, Davies PDO, Cushing A. Social impact of respiratory infections. Chest 108: 63S-69S; 1995.

28. Ryan, p. 391.

29. Ryan, p. 391.

30. Frieden TR, Fujiwara PI, Washko RM, Hamburg MA. Tuberculosis in New York City - turning the tide. New England Journal of Medicine 333: 229-233; 1995.

\section{BIOGRAPHY}

Caralee E. Caplan received a B.A. from Harvard University (Cambridge, Massachusetts) in 1994. She is currently a first-year student at McGill University (Montreal, Quebec) pursuing both an M.D. and an M.A. degree in English.

Copyright (C) 1995 by MJM 